\title{
Silvestro da Prierio and the Pomponazzi Affair
}

MICHAEL TAVUZZI

Summary: The Italian Dominican friar Silvestro Mazzolini da Prierio(14561527), known as Prierias, served as Master of the Sacred Palace during the pontificates of Leo X, Adrian VI and Clement VII. He is chiefly remembered for his involvement in the cases of Luther and Reuchlin and an epistolary exchange with Erasmus. In this paper it is argued that he also played an important role in the Pomponazzi affair. Furthermore, Prierias' intervention largely explains Bartolomeo Spina's own polemics against both Pomponazzi and Cajetan.

The sequence of events which constituted the famous "Pomponazzi Affair" 1 is well known. ${ }^{1}$ On the 19 th of December 1513, the fifth Lateran Council issued a decree condemning the Averroistic interpretation of Aristotle's De anima which had affirmed the unicity of the human intellect (both passive and active) and the mortality of the individual human soul. The decree also prescribed that thereafter even teachers of philosophy who dealt with the matter were bound to present and defend the traditional Christian doctrine. It was because of the latter proviso that Thomas de Vio Cajetan, at the time not yet a cardinal but attending the Council as Dominican Master General, voted against the decree. Cajetan believed that this ordination blurred the distinction between philosophy and theology and threatened the autonomy proper to the natural philosopher.

In 1516 Pietro Pomponazzi, a professor of philosophy in the Faculty of Arts of the University of Bologna, published a treatise entitled De immortalitate animae. Pomponazzi claimed that the composition of this work was provoked 
48 / Renaissance and Reformation / Renaissance et Réforme

by the question of whether the position of saint Thomas on the immortality of the soul corresponded to that of Aristotle. This question seems to have been posed to him by one of his students, the Dominican friar Girolamo Natali da Ragusa. In his treatise Pomponazzi followed the position of Alexander of Aphrodisias and argued that the authentic teaching of Aristotle was that the individual human soul is of its essential nature mortal. Pomponazzi was immediately attacked for holding this position by several philosophers and theologians including Ambrogio Fiandino and Gaspare Contarini. He was attacked as well by Vincenzo Colzado da Vicenza, to mention just one of the several Dominicans who entered the fray in its early stages. Pomponazzi responded to these attacks by composing in 1517 and publishing early in 1518 a further tract entitled Apologia. At this point and possibly at the request of Leo $\mathrm{X}$, the famous Agostino Nifo intervened and composed the de immortalitate animae libellus. Pomponazzi sought to reply to Nifo's attack by writing a third treatise, the Defensorium.

On the 13th of June 1518 Leo X demanded a retraction from Pomponazzi, but nothing came of this because of a swift intervention in Pomponazzi's favour by Cardinal Pietro Bembo. Nonetheless, when a little later Pomponazzi tried to publish the Defensorium the Inquisitor in Bologna refused permission since the work was not accompanied by the refutation of mortality required by the ordinations of the Fifth Lateran Council. But it seems that Pomponazzi was either unwilling or simply felt unable, if he were to remain coherent, to write such a refutation himself. Instead Pomponazzi chose to write a highly complimentary letter to Crisostomo Iavelli da Casale, the regent master of the Dominican studium generale in Bologna, asking him to write an appropriate theological refutation of his position which could complement the text of the Defensorium and thereby render possible its publication. Iavelli replied to Pomponazzi with a letter accepting the task, and in his Solutiones he published a concise, point by point refutation of Pomponazzi's position. This arrangement seems to have satisfied Church authorities. Pomponazzi's Defensorium was published together with the Solutiones in 1519 and again in 1525.

Iavelli later published two further works in which he dealt with the matter of the immortality of the soul. In 1534, he published the Quaestiones in III De anima and in 1536 the Indeficientia animae humanae. In the second of these works Iavelli gave an account of the entire affair, reproducing Pomponazzi's letter to him and indeed recapitulating the entire Renaissance debate on the complex question of the immortality of the soul. He also examined the controversial interpretations of the Aristotelian text which had been proposed. 
In both works Iavelli did not hesitate to criticize Cajetan and to identify him as the ultimate source of the errors of Pomponazzi. Iavelli pointed out that Cajetan had himself argued, in his commentary on Aristotle's De anima completed in 1509 and published in 1510, that Aristotle had not taught the doctrine of the immortality of the soul.

$* * *$

Iavelli was not the first to link Pomponazzi and Cajetan and to impute to Cajetan the responsibility for the supposed errors of Pomponazzi. This had already been done openly by another Dominican, Bartolomeo Spina da Pisa. His attack on both Cajetan and Pomponazzi took the form of three tracts written during the second half of 1518: the Propugnaculum Aristotelis de immortalitate animae contra Thomam Caietanum, a critique of Cajetan's commentary on Aristotle's De anima; the Tutela veritatis de immortalitatis animae contra Petrum Pomponatium mantuanus, directed against Pomponazzi's De immortalitate animae; and the Flagellum in Apologiam Paretti, a response to Pomponazzi's Apologia. ${ }^{2}$

What motivated Spina's attack against both Cajetan and Pomponazzi? Scholars who have dealt with this question have hitherto answered it in terms of vague references to either Spina's conservative and reactionary temperament or his aggressive and mischievous personality. Gilson, while not proposing an alternative explanation, has added a word of caution: "Nous sommes trop loin des événements pour juger en connaissance de cause."3

Spina himself justified his attack by vaunting his love for truth and expressing a concern for those who were likely to be harmed by the pernicious theses advocated by his two antagonists. He also protested his extreme reluctance at attacking Cajetan whom he had praised less than a year earlier in the preface to his 1517 edition of Cajetan's commentary on Aquinas' Summa Theologiae, IIa-IIae.

Spina's attack against Cajetan provoked an immediate reaction from his religious superiors. Though written in 1518, Spina's three tracts were only finally printed on the 10th of September 1519. A little less than two months later, on the 24th of october 1519, Francesco Silvestri da Ferrara, who was then Vicar General of the Observant Congregation of Lombardy of which Spina was a member, sharply reprimanded him for having written against Cajetan and for having published his tracts without first obtaining his permission. The copies of Spina's publication were confiscated. ${ }^{4}$ 
But it was not Spina's argument against Cajetan that Spina's superior found objectionable. After all, Francesco Silvestri himself had criticized the position of Cajetan in his Commentaria on aquinas' Summa contra Gentiles published only $1 \mathrm{n} 1524$, but already completed by 1517 . But he had done so in a courteous manner, never naming Cajetan and employing the conventional formula "nonnulli Thomistae." It was the personal and bellicose nature of Spina's attack on cajetan that Francesco Silvestri seems to have deemed offensive.

Nonetheless, even in the short run, the incident did no harm whatsoever to Spina's further career. He continued as conventual lector in the convent of San Domenico in Modena and as vicar of the Inquisitor in Modena and Ferrara, Antonio Beccari da Ferrara. Not long afterwards he was appointed bachelor of the Sentences for the academic years 1524-1525 and 1525-1526 in the Dominican studium generale in Bologna. In the academic years 1530-1531 and 1532=1533, he served as regent master while spending the intervening year as assistant to the Dominican Master General Paolo Butigella. Later he held the titular office of Provincial of the Holy Land, and from 1536 he filled the chair of theology in via Thomae in the University of Padua. In 1545 he was appointed Master of the Sacred Palace by Paul III. At the time of his death in 1546 Spina enjoyed a considerable reputation as a theologian and was one of the major personages of the opening session of the Council of Trent.

But Spina's spectacular later career must not make us lose sight of his modest status when he first launched his polemics against Cajetan and Pomponazzi in 1518. At the time Spina held only the minor post of conventual lector in the convent of San Domenico di Castello in Venice and did not even have a university degree in theology. He was not a particularly significant person nor could he have possibly believed that he could directly attack Cajetan with impunity on the basis of his own standing. In addition, despite Francesco Silvestri's immediate intervention Spina's further advancement was in no way impeded. With these circumstances in mind, one can only be perplexed. Can the audacity of Spina's attack against Cajetan be explained solely by vague references to his "conservatism," or to his aggressive personality, or even to the noble reasons which he himself explicitly adduces? Could it be that when Spina attacked Cajetan in 1518 he did so without hesitation because he was in fact acting on behalf of a more powerful person who, at least for the sake of decorum, could scarcely attack a cardinal openly?

I suggest that the answer to this question is to be found in a passage of the Flagellum. Spina's response to Pomponazzi's Apologia. In this passage Spina 
reacts furiously against a passage of the Apologia in which, at least according to Spina, Pomponazzi had attempted to bolster his case by claiming that the Master of the Sacred Palace was sympathetic to his position. In effect, in this passage of the Apologia, Pomponazzi had said that he had tried to discover whether the Master of the Sacred Palace had written against him as had been claimed by some Dominicans in Bologna. The result of this had been that Pomponazzi had been assured by a Dominican arriving in Bologna from Rome that the Master of the Sacred Palace had not written against him. He had been informed, nonetheless, that the Master of the Sacred Palace might have written against "some (Dominican) confrere" who had also argued that Aristotle held the opinion that the human soul was mortal. ${ }^{6}$

It is important to notice that this passage by Pomponazzi preceded Spina's literary intervention inm the whole affair and that it is not so innocuous as might appear at first sight. The reference to "some (Dominican) confrere" who, like Pomponazzi, held the opinion that Aristotle had not taught the immortality of the soul and against whom the Master of the Sacred Palace might perhaps have written, can only be a reference to Cardinal Cajetan. Pomponazzi's rather ironic reference to "some (Dominican) confrere" is both mocking and provocative. What Pomponazzi is really saying is that, despite all the threats made by the Bolognese Dominicans, the Master of the Sacred Palace was not in the position to move against him because he could not do so without implicating Cajetan as well.

In his reply to this passage Spina accuses Pomponazzi of lying about the attitude of the Master of the Sacred Palace. He praises him and stresses both his learning and his zeal for the faith. He claims that the Master of the Sacred Palace had not moved against Pomponazzi only because "many" held a similar position and not because he was sympathetic to it. Spina claims that in fact the Master of the Sacred Palace abhorred Pomponazzi's writings and that Pomponazzi could discover this for himself if he examined the Master of the Sacred Palace's works. ${ }^{7}$

Two points here deserve our attention. Spina's reference to the "many" who held a similar position and thereby made it impossible for the Master of the Sacred Palace to proceed against Pomponazzi coincides with the allusionto "some (Dominican) confrere" made by Pomponazzi. There can be no doubt about the identity of the single referent of these two expressions. There was at that time no Dominican other than Cardinal Cajetan who defended a position in any way similar to Pomponazzi's. Spina's employment in his response to Pomponazzi of the more inclusive "many" just shows that Pomponazzi's jibe 
had hit the mark. Second, in the passage Spina refers to the Master of the Sacred Palace as "my special teacher"8 and speaks of the opinions and works of the Master of the Sacred Palace as something with which he was intimately acquainted.

\section{****}

The Master of the Sacred Palace in question was the Dominican friar Silvestro Mazzolini da Prierio (1456-1527) who held the office from the second half of the pontificate of Leo X, through that of Adrian VI and into the first half of that of Clement VII. ${ }^{9}$ Silvestro Mazzolini, who was usually called "Prierias," is known to historians chiefly for his participation in the Roman juridical processes against Reuchlin and Luther and for his epistolary exchange with Erasmus. His life as a whole, however, has not been adequately studied, and his many works have not received the attention that they deserve. It is not surprising therefore that his involvement in the Pomponazzi affair has been generally overlooked by scholars. ${ }^{10}$ Nonetheless, an awareness of the role played by Prierias provides a valuable insight into the hidden dynamics of the affair and largely explains Spina's intervention.

Prierias entered the Dominican Order in the convent of San Domenico in Savona in 1471. He completed his initial theological studies in the Dominican studium generale in Bologna where he was a student of Pietro Maldura da Bergamo (+1482) and Dominic of Flanders (+1479). His fellow students at the time included Girolamo Savonarola and Paolo Barbo da Soncino (+1495). After some years of apostolic work Prierias returned to the Bolognese studium and a studens formalis in 1487 and once again counted Savonarola among his peers. During the academic year 1489-1490 he held the post of master of students and taught logic and astronomy. He served as biblical bachelor from 1491 to 1493. After a further period of apostolic work he exercised the office of bachelor of the Sentences and graduated as a Master of Theology of the University of Bologna in 1498. He held the post of regent master in the Bolognese studium from 1499 to 1502 . In that same year Prierias was appointed regent master in the studium of the convent of Santi Giovanni e Paolo in Venice. He refused this post to accept a call to the chair of metaphysics in via Thomae in the University of Padua, but he was not confirmed in the position. He subsequently served as prior of Dominican convents in Milan, Verona and Genoa. In 1508 Prierias was elected Vicar General of the Observant Congregation of Lombardy for a biennium and was appointed 
inquisitor in Brescia and Crema. From 1510 to 1512 he held concurrently the offices of prior of the convent of San Domenico in Bologna and of regent master in its studium. In 1512 he was appointed inquisitor in Milan and Lodi and played an important role in the opposition to the conciliabulum of PisaMilan. He further served as prior of Dominican convents in Cremona and Venice until his appointment as professor at the University of Rome and Master of the Sacred Palace in December of 1515. He died during the Sack of Rome in 1527.

Spina not only knew Prierias but was also particularly close to him. Spina had not always been a member of the Observant Congregation of Lombardy. When he transferred to that congregation from the Roman-Tuscan Congregation in 1509 he was received by Prierias who was then its Vicar General. Spina subsequently studied in the Dominican studium generale in Bologna during the academic years 1510-1511 and 1511-1512 when Prierias was serving both as prior of the convent of San Domenico and as regent master of the studium. When Spina attacked Cajetan and Pomponazzi he was a member of the convent of San Domenico di Castello in Venice where Prierias had been prior before he was appointed Master of the Sacred Palace by Leo X in December 1515. Prierias had been responsible for Spina's assignation to that convent on the 1st of January $1515^{11}$ and probably also for his appointment as its theological lector. Finally, when Spina's three tracts were published in 1519 they were dedicated to Cardinal Domenico Grimani (1451-1523). Grimani, a convinced Thomist, was Prierias' great patron in Rome and had influenced Leo X's decision to appoint him Master of the Sacred Palace and a professor of theology at the Sapienza.

Prierias was also close to Spina. There are, as far as I have been able to discover, three explicit references to Spina in Prierias' works the earliest in the Conflatum ex S. Thoma, a thematic anthology of Aquinas' works accompanied by a commentary by Prierias. The Conflatum was projected as a great work which, if it had been completed, would have rivalled in scope the classic commentaries of Cajetan on the Summa Theologiae and of Francesco Silvestri on the Summa contra Gentiles. The fact that it was not completed was largely due to interruptions such as those caused by the case of Martin Luther and Prierias' subsequent preoccupation with the "sect of the witches" and especially to the poor health that debilitated Prierias during the last years of his life. Prierias tells us that he completed about half the work, corresponding more or less to the materia; I dealt with by Aquinas in the Ia and the Ia-IIae of the Summa Theologiae. ${ }^{12}$ Furthermore, of the completed parts of the Conflatum only a 
small portion was actually printed. The section published in the first volume printed in Perugia in 1519 covers the material treated by Aquinas in the first 45 questions of the Prima pars.

The other completed but never printed parts of the Conflatum included Prierias' commentary on the discussion of the intellective soul presented by Aquinas in the second half of the Prima pars. In his commentary Prierias had dealt explicitly with the problem of the immortality of the soul. It is important to note that these "unpublished" parts of the Conflatum were certainly in circulation in manuscript form and presumably readily available. ${ }^{13}$ They seem to have circulated even long after Prierias' death as they are occasionally cited by later theologians such as Mattia Gibboni da Aquario $(+1591) .{ }^{14}$ The Genoese Dominican historian Giovanni Maria Borzino (+1696) mentions that in his life the manuscript of the second volume of the Conflatum was still in the library of the convent of San Domenico in Bologna. ${ }^{15}$ It was to these never printed parts of the Conflatum that Spina referred when he spoke of the works of Prierias that Pomponazzi ought to have consulted before daring to speak about the attitude of the Master of the Sacred Palace.

The first volume of the Conflatum is supplemented by a letter of the reader in which Prierias presents an inventory of his previous works. It is in this context that we find his first explicit reference to Spina. Prierias tells us that he had entrusted to Spina the task of revising some of his very early works such as the Compendium dialecticae which had been published in Venice in 1496. Prierias refers to Spina as his "beloved and very erudite disciple."16

Prierias' two other explicit references to Spina are of much greater importance because they occur within a lengthy discussion of the issue of the immortality of the soul. This discussion is presented in his De Strigimagarum Daemonumque Mirandis, Libri Tres, first published in Rome in $1521{ }^{17}$ but, as indicated in the work's conclusion, completed on the 20th of November $1520 .{ }^{18}$ This work is an inquisitorial handbook concerned with the procedure to be followed in suspected cases of witchcraft and is largely derived from the Malleus Maleficarum by Jakob Sprenger and Heinrich Krämer (Institor). Perhaps the only really original parts of the work are the third, fourth and fifth chapters of the first book. In these preliminary chapters Prierias deals in turn with the issues of the immateriality and subsistence of the human soul, its immortality and the authentic opinion of Aristotle on the matter. In the fifth chapter Prierias refers expressly to the case of Pomponazzi and it is precisely in this context that he mentions Spina. This extremely interesting material has not been noticed by any of the scholars who have previously dealt with the 


\section{Pomponazzi affair. ${ }^{19}$}

Prierias' attitude to Pomponazzi is uncompromising. After accusing him of having distorted his words in the Apologia he tells of his reaction on reading Pomponazzi's De immortalitate animae and of his conviction as to the harm that the work was likely to do. He praises the Venetian Senate for having consigned the work to the flames, an example which he insists should have been followed everywhere. He praises his "most erudite and beloved son and disciple, Spina, for having refuted the position of Pomponazzi and stresses that he had himself already written against "that kind of position" even before Pomponazzi had composed the De immortalitate animae. ${ }^{20} \mathrm{He}$ concludes the fifth chapter by reiterating his claim that he had written on these matters even before Pomponazzi and his conviction that the position of Pomponazzi had been successfully refuted by Spina and by another of his former students, Girolamo Fornari da Pavia. ${ }^{21}$

This material from the De Strigimagarum warrants several remarks. First, since the De Strigimagarum was completed by the 20th of November 1520 , these opening chapters of the first book must have been written at the same time or just a little after Spina's reprimand from Francesco Silvestri. Thus when Spina was himself attacked for his polemics against Pomponazzi and Cajetan - and defending Prierias - Prierias stood fully behind him.

Second, the point-by-point similarities between the passage on Pomponazzi in Prierias' De Strigimagarum and the passage from Spina's Flagellum discussed above are too striking to be coincidental. They both contain expressions of anger at Pomponazzi's attempt to manipulate Prierias' inaction for his own interests. They both insist on Prierias' reaction of disgust and concern for the simple, which had been provoked by Pomponazzi's De immortalitate animae. They both refer to Prierias' opposition to positions similar to that of Pomponazzi held by others. They both stress that Prierias' authentic position can easily be discovered by reading his works. It is unfortunate that these works, the completed but not printed parts of the Conflatum, seem to be no longer extant. It would be pertinent to compare the arguments employed by Prierias against Cajetan with the arguments employed by Spina against Cajetan and Pomponazzi.

Third, Prierias' observation that Pomponazzi's work should not be entitled "On the Immortality of the Soul" but "On the Mortality of the Soul" is also found in the opening paragraph of Spina's Tutela veritatis. ${ }^{22}$

Did Prierias have Spina's works open in front of him while writing this passage of the De Strigimagarum or had Spina's tracts been simply an echo of 
Prierias' words to begin with? Either way, one can hardly doubt that there must have been some kind of understanding between the two men, and the motive force behind Spina's attack on Cajetan and Pomponazzi is evident. It was not a matter, in the first place at least, of either an entrenched conservatism or of a naturally polemical disposition. Spina was simply acting on Prierias' behalf in a conflict in which Prierias himself could not become openly involved.

The overall scenario is clear. Prierias had been opposed to the position of Cajetan since 1510 when it had first been proposed in the commentary on Aristotle's De anina. Sometime during the years between 1510 and 1515 Prierias wrote against Cajetan in those parts of the Conflatum which would never be printed. Prierias probably did not mention Cajetan by name but employed some conventional expression such as "nonnulli Thomistae" or "quidam moderni." Indeed the first volume of the Conflatum printed in 1519 abounds with criticism of Cajetan on many diverse speculative issues. This is so much the case that one cannot but wonder whether the primary intent of Prierias' commentary in the Conflatum was not the refutation of Cajetan's particular interpretation of the doctrine of Aquinas. Yet Cajetan is never mentioned by name except for a single instance rich in philosophical implications. ${ }^{23}$ Nevertheless the identity of the referent of Prierias' critical remarks is clear as they usually focus on direct citations from Cajetan's commentary on the Summa Theologiae.

When in his capacity as Master of the Sacred Palace and inquisitor and book censor in Rome Prierias examined Pomponazzi's De immortalitate animae in 1516 he must have looked upon it, correctly or otherwise, as the result of the influence of Cajetan. Yet, precisely because Cajetan was then Master General he could not go so far as to condemn the book outright.

What must really have provoked Prierias' anger was Pomponazzi's attempt in the Apologia, completed on the 23rd of November 1517 and published early in 1518 , to manipulate his reticence so as to cast him as a sympathizer. Prierias must also have found especially irritating Pomponazzi's obvious reference to Cajetan and his implicit reference to Prierias' consequent impotence. Pomponazzi's remarks were particularly cutting in the light of Cajetan's elevation to the cardinalate which had taken place in July 1517 . At that point Prierias is likely to have exerted his influence as Master of the Sacred Palace so as to induce Leo $\mathrm{X}$ to demand the retraction which was called for in June 1518 and which brought the entire "Pomponazzi affair" to a climax. Pomponazzi, however, was able to defuse the matter by securing the intervention of Cardinal Pietro Bembo. 
It was precisely at this point, sometime toward the beginning of 1518 and at a time when Prierias' chances of taking radical steps against Pomponazzi must have seemed slim indeed, that Spina began to compose the three tracts which were published in 1519. But did Prierias propose the attack on Cajetan and Pomponazzi to Spina or was it Spina himself, convinced that Prierias would approve and indeed defend him if need be, who took the initiative? If we are to believe Spina the latter would seem to be the case. ${ }^{24}$ This might just be a classic case of protesting too much. Whatever the case, when Spina attacked Cajetan and Pomponazzi it was surely on Prierias' behalf and Prierias is likely to have known about it and supported him.

$* * *$

The aim of this paper has been to show the previously unnoticed but important role played by Silvestro da Prierio in the Pomponazzi affair, and thereby to account for the hitherto unexplained intervention by Bartolomeo Spina. But it has also cast some light on an instance of conflict between Silvestro da Prierio and Thomas de Vio Cajetan.

The relationship between these two eminent sixteenth-century ecclesiastics was a long-standing one and much remains to be studied. Their first contact went back to 1488 when Prierias was already a renowned preacher and was about to begin teaching logic in the Dominican studium generale in Bologna. At the time Cajetan was a young student of 19, brilliant but feeble, who had just been sent to Bologna from the unreformed Dominican province of the Kingdom of Naples to follow the course in artium. After a few months Cajetan left Bolognabecause of poor health and settled back into the easy conventuality of his house in Gaeta. When he was well enough to recommence his studies he did so in the studium of the unreformed convent of Sant'Agostino in Padua. The relationship between the two did not end in fact until the Sack of Rome in 1527, the occasion of Prierias' death and of Cajetan's greatest humiliation. It was a relationship which involved periods of intense cooperation and periods of conflict and rivalry between two Dominican friars who represented two different conceptions of religious life and who were the principal advocates of two competing Thomistic schools. This complex matter in itself deserves further study. 


\section{Notes}

1. See particularly: F. Fiorentino, Pietro Pomponazzi. Studi storici sulla scuola bolognese e padovana del secolo XVI (Florence, 1868), 156-241; E. Verga, "L'immortalità dell' anima nel pensiero del Card. Gaetano," Rivista di Filosofia Neo-Scolastica, XXVII (1935), suppl. 21-46; M.-H. Laurent, "Introduction. Le Commentaire de Cajétan sur le De anima" in Thomas de Vio Cardinalis Caietanis, Scripta philosophica, ed. P. I. Coquelle (Rome, 1938), I, vii-liii; C. Giacon, La seconda scolastica, I-III (Milan, 1944-1951), I, 53-90; É. Gilson, "Autour de Pomponazzi. Problématique de l'immortalité de l'âme en Italie au début du XVI siècle," Archives d'Histoire Doctrinale et Littéraire du Moyen Age, XXXVI (1961), 163279, and "L'affaire de l'immortalité de l'âme à Venise au début du XVI' siècle," Umanesimo europeo e umanesimo veneziano, ed. V. Branca (Florence, 1963), 31-61; G. Di Napoli, L'immortalità dell'anima nel rinascimento (Turin, 1963), 179-338; M. L. Pine, Pietro Pomponazzi: Radical Philosopher of the Renaissance (Padua, 1986), 124-234.

2. Spina's three tracts were completed in 1518. They were published in 1519 as part of a wider collection entitled Opulscula [sic] edita per fratrem Bartholomeum de Spina pisanum ordinis predicatorum ... Venetijs, per Gregorium de Gregoriis, 1519 die X mensis septembris.

3. É. Gilson, art. cit. (1961), p. 196. The reservation is repeated in art. cit. (1963), p. 43.

4. “1519, die 24 Octobris. - Ego fr. Hieronymus de Laude, prior Bononiensis, de communi consilio patrum discretorum dicti conventus, misi ad librorum venditorem qui habebat quosdam libros impressos Venetiis contra. Rev.mum D. Card. S. Sixti: De immortalitate animae humanae, et feci omnes quotquot habere potui, deferri in conventus sub deposito, et scripsi manu propria fratri Bartholomeo Pisano, auctori predicti libri, praecipiens ei in virtute sanctae obedientiae, nec aliquem librum qui in sua esset potestate cum illo titulo contra Thomam Caietanum et Peretum, vendere vel publicare auderet, nisi expressam in scriptis ostenderet se habere licentiam a rev.do vicario generali etc. Ipse rescripsit manu propria inter cetera, quod libellum contra Thomam Caietanum imprimi fecerat sine licentia et scitu rev.di vicarii congregationis Lombardiae, et de industria id fecerat, ne Rev.mus Cardinalis praedictus causam haberet indignationis contra congregationem, sed tantum contra ipsum fratrem Bartholomeum, qui dixit se zelo Dei et pro salute studentium tale opus edere voluisse. Postquam rev.dus vicarius, scilicet magister Franciscus de Ferrara id scivit, acriter reprehendit ipsum fratrem Bartholomeum, tunc lectorem Mutinensem. Ego idem fr. Hieronymus scripsi Rev.mo Cardinali S. Sixti quod Pater vicarius congregationis non cencessit licentiam fratri Bartholomeo Pisano publicandi librum praedictum." Lib. cons. conv. Bon., f. 36Av, cited by R. Creytens, "Les vicaires généraux de la congrégation O.P. de Lombardie," Archivum Fratrum Praedicatorum, XXXII (1962), Pp. 256-257.

5. In Summam contra Gentiles, II, c. 79, n. 8.

6. "Diu etiam et per litteras et per amicos curavi: habere quedam tractatum viri eminentissimi Magistri Silvestri de Prierio sacri palatii apostolici magistri: quem quidam ex eiusdem ordinis fratribus: adversus nos composuisse rettulerunt. Verum eum proximus his diebus: Magister Ioannes de Augusta frater eiusdem ordinis ex urbe rediens: ad nos se contulisset retulit: Magistrum Silvestrum nihil adversus nos scripsisse quamquam forsan scripsisset 
adversus quedam confratrem: asserentem Arist. sentire animos esse mortales." Apologia, Bononiae 1518, II, Car. XXIIIr, b.

7. "Audes et intermiscere mendacia sicut supra de magistro Vincentio Vincentin, sic in presenti loco de Magistro sacri pallatii viro doctissimo, integerrimo ac fidei zelantissimo preceptore meo singularissimo. Licet enim librum ut hereticum non damnaverit propter hoc quod contineat demonstrative non posse probari animam esse immortalem vel philosophus hoc non tenere et huiusmodi, que a multis opinata sunt. Non tamen librum commendavit, in hoc quod astruis demonstrative probari oppositum per rationes naturales quas induxisti, et hoc esse simplicite et absolute verum: illud vero esse deliramentum et principiis philosophi repugnans, et quod illud praedicarunt legumlatores fuisse deceptores. Hec et alia plura extrema damnatione digna, quibus liber ille tuus refertus est non commendavit Magister sacri pallatii: immo abhorruit. Quod certa experireris, si sua principaliter interesset. Sed de his satis." Flagellum, f. K. IVv, a.

8. É. Gilson, art. cit. (1963), p. 38, has mistakenly read Spina's “preceptore meo singularissimo" as referring to Vincenzo Colzado.

9. The only attempt at a biography of Prierias remains F. Michalski, De Silvestri Prieratis Ord. Praed. Magistri Sacri Palatii (MCCCCLVI-MDXXVIII). Vita et Scriptis (Münster, 1892). I hope to complete a monograph $\mathrm{a}=$ on Prierias in the near future in which the biographical details concerning both Prierias and Spina introduced in this paper will be documented.

10. For example, the most recent account of the affair has only two passing references to Prierias which seem to make of "the Master of the Sacred Apostolic Palace, Silvestro Mazzolini" and "Silvestris de Prierias, a theologian in the court of Leo X" two different persons (see M. L. Pine, Op.cit., p. 126).

11. “Anno MDXIV. More Veneto [= 1515] die I. Januarii. Ego Fr. Silvester de Prierio Prior proposui Ven. PP. an vellent habere in filium sui Conventus P. Fr. Bartholomaeum de Pisis, et responderunt ut infra. In primis Ego idem Prior sum valde contentus etc." Liber consiliorum conventus S. Dominici de Castello, cited by F. Cornelio, Ecclesiae Venetae Antiquis Monumentis (Venetiis, 1749), VII, p. 325.

12. "Conflatum vero ipsum ex Divo Thoma propter sui vastitatem, neodum plene expletum est: sed quantum ad textum quidem, totum perfeci uniformiter: excepto eo quod secundum secundi ne magnitudo eius excresceret in immensum, edidi quasi per modum epithomatis: sic tamen quod nullum verbum s. Thomae mutatum est, et nullum verbum doctrinalem omissum: et forte hec pars ceteris gratior erit. Commentaria autem nostra in Conflatum, expleta sunt quo ad primum volumen plene: quo ad secondum idest primum secundi expleta sunt ex parte Magna, sed non plene: quia inde me invitum Martinus avulsit: cito vero ea deo favente explebo: sed quantum ad secundum secundi et tertium sive ultimum volumen puto commentandam relinquam alicui discipulorum meorum: nisi beatissimus dominus noster Leo sua bonitate qua me semper est prosequutus reddat religioni: ubi iam a prelaturis immunis et quietus omnia brevi tempore explerem. Quod si deo et domino nostro beatissimo faventibus effecere iam lentissimus mortem obibo." Conflatum (Perusiae, 1519), I, f. 299v.

13. The manuscript circulation of these unprinted parts of the Conflatum is evident from the references to this work in contemporary chronicles. See the entries on Prierias in Alberto de 
Castello's Chronica Brevissima, second edition of 1516, published by R. Creytens, "Les écrivains dominicains dans la chronique d'Albert de Castello," Archivum Fratrum Praedicatorum, XXX (1960), pp. 298, 300; and in Leandro Alberti, De viris illustribus Ordinis Praedicatorum (Bononiae, 1517), f. 140v.

14. Francisci Silvestri Ferrariensis. . Quaestiones luculentissimae in tres libros De Anima. Cum additionibus as easdem. . . R. P. F. Matthiae Aquarij. . . (Venetiis, 1601), pp. 109, 138.

15. G. M. Borzino, Memoria Domenicana Genovesi, Biblioteca Apostolica Vaticana, Cod. Vat. Lat. 9451, f. $109 \mathrm{v}$.

16. "Deinde de textum dialectice, qui quoniam prima fronte quaedam subtiliora perse fert, lectores deterret: cum tamen dilectus et eruditissimus discipulus meus Bartholomeus Pisanus. .." Conflatum, I, f. 299v.

17. Impressum Rome per Antonium Bladis de Asula: die XXIV Septembris. Anno D. MCCCCCXXI. I cite the edition, Romae, In aedibus Po[puli] Ro[mani] MDLXXV.

18. De Strigimagarum, p. 262.

19. For example, G. Di Napoli in his account of the affair (see op. cit., p. 298) remarks: "Nell' Apologia II (42) il Pomponazzi ricorda tra i contradittori i domenicani Vincenzo Colzade da Vicenza e Silvestro Prierias ... dell'uno e dell' altro noi non possediama scritti riguardo al problema dell'immortalità."

20. "Et si mei non est instituti, quid de immortalitate nostri animi senserit philosophorum sapientissimus Aristoteles afferre, quippe qui non humana authoritate probare cupio quod sentio: incidenter tamen de sententia et opinione Arist. in re hoc cogor rationem habere, quo me ipsum ab ijs quae mihi falso et leviter (idest me non audito) verbo aut scripto Petrus Pomponatius in Apologetico sup imposuit, expurgem: quod scilicet viso suo libro quem de immortalitate (imo de moratalitate) animae cudit, subriserim et probarim. Haec enim falso et leviter dicuntur: quin potius eo viso, ingemui ac dolui, quod ita catholica fides in parvulorum entibus per christianos elidatur, et enervetur, et erroribus innumeris sit occasio data, quod iam experientia docet: et si meum fuisset, in librum per ignes, Venetorum exemplo, animadvertissem. Illustrissimos autem dominos Venetos potius laudavi, et miratus sum, quod nulla habita ratione amicitie ad Perretum Venetijs id effecerunt, quod unique faciendum erat, tantum scilicet scelus flammis ultricibus expiasse. Quamquam vero copiosissime luculenter et eruditissime, dilectus et filius, et discipulus Bartho. Pissanus ordi. Praedi. eiusmodi opinionem confutarit, adducam tamen et ego quae quondam in Commentaris primi voluminis nostri conflati contra eiusmodi opinionem, antequam scriberet Perretus, compendiose edideram, etsi nec in hanc diem propalata sint." De Strigimagarum, p. 19.

21. "At Perretum respondi minime, quia de his ante eum scripseram: nunc vero respondere non oportet: quia per Fratrem Hieronymum Fornarium Bachalarium, et per Fratrem Bartholomaeum Pisanum fundamenta eius eversa sunt." De Strigimagarum, p. 42.

22. "Castiga igitur propositum: et hunc qui libello huic tuo proprius est prepone titulum, petri pomponatii mantuani tractatus de moratalitate anime intellective." Tutela veritatis, f. D IIIr, a. 
23. “. . quidam dicunt idest caieta. quod [St. Thomas] ademit sibi omnem viam concordie cum doctrina arist. iuxta suam expositionem: quia tenet arist. putasse animas intellectivas immortales: et numeratas secundum numerum corporum: et constat arist. tenuisse generationem eternam: ex quibus manifeste sequitur animas humanas esse actu infinitas: quod hic decernitur impossibile: hec ille: qui ex his vult habere quod oportet s. tho. aut negare aristotelem: aut dicere animas rationales de mente eius esse mortales: de quo infra erit sermo. Sed ego dico primo aristotelem erasse in eternitate generationis: et consequenter eum negare non solum non inconvenit: sed est necesse: non solum secundum fidem, sed philosophice loquendo. .." Conflatum, I, f. 48v.

24. "Non potui ultra resistere spiritui sancto aut zelo animarum et veritatis frenum imponere, qui solus (deus testis est) me impulsit ad scribendum." This statement is in the letter Ad lectorem at the end of the Flagellum. 